Wayne State University

DigitalCommons@WayneState

Communication Faculty Research Publications

Communication

$7-1-2001$

\title{
Telecommunications Reform In Botswana: a Policy Model for African States
}

Patricia K. McCormick

Wayne State University, dz7089@wayne.edu

\section{Recommended Citation}

McCormick, Patricia K. "Telecommunications reform in Botswana: a policy model for African states." Telecommunications Policy 25.6 (2001): 409-420.

Available at: http://digitalcommons.wayne.edu/commfrp/1

This Article is brought to you for free and open access by the Communication at DigitalCommons@WayneState. It has been accepted for inclusion in Communication Faculty Research Publications by an authorized administrator of DigitalCommons@WayneState. 
NOTICE IN COMPLIANCE WITH PUBLISHER POLICY: This is the author's version of a work that was accepted for publication in Telecommunications Policy. Changes resulting from the publishing process, such as peer review, editing, corrections, structural formatting, and other quality control mechanisms may not be reflected in this document. Changes may have been made to this work since it was submitted for publication. This version has been formatted for archiving; a definitive version was subsequently published in Telecommunications Policy, 25(6). July 2001. pp. 409-420. Available online at: http://dx.doi.org/10.1016/S0308-5961(01)00014-3 


\title{
Telecommunications reform in Botswana: a policy model for African states
}

PATRICIA K. McCORMICK, Department of Radio, TV and Film, Howard University, 525 Bryant St., NW, Washington, DC 20059, USA

Corresponding authorｅmail:pmccormick@howard.edu tel:202-806-7929

\begin{abstract}
Since the mid-1990s, Botswana has pursued a policy of telecommunications liberalisation. This article, based on fieldwork conducted in Botswana in the summer of 2000, analyzes several notable aspects of the process of reform and denotes those worthy of emulation by other African states. The participation and protection of domestic telecommunication users, transparency in decision-making, the creation of an independent regulatory agency, and the introduction of competition in the form of private cellular service providers are among those policy features that are recommended for replication. Various facets of the tendering process and subsequent licences granted to the mobile operators as well as recent legislation are also examined and commended.
\end{abstract}

Keywords Policy; Reform; Africa; Botswana; Regulation and regulatory agency

Reform of the telecommunications sector has become globally accepted as essential to promote network efficiencies and extend the infrastructure to rural areas. The strategic importance of the sector is beyond dispute. The telecommunications sector is critical in enabling countries to achieve social and economic development goals as well as compete in the international economy, since effective use of electronic communication permits improved coordination in the distribution and production of goods and services. The telecommunications network is the most basic form of infrastructure for it serves as a platform and a catalyst for other industries, facilitating forward and backward linkages within the economy. As developing countries modernize their economies, emphasis is placed on upgrading the telecommunications infrastructure. To facilitate this process reform of the sector is imperative.

Reform and privatization of the telecommunications sector have diffused rapidly internationally, yet Africa remains a laggard in this policy diffusion process. An exception to this general state of affairs is Botswana whose government perceived insufficient telecommunications services as an impediment to sustainable development, and it is this perception that has served as the impetus for sector restructuring. Botswa- na's telecommunications liberalisation policies can be considered a model for other African states to emulate, especially member states of the Southern African Development Community (SADC). In examining Botswana's telecommunications policies, this article seeks to contribute to a dialogue among those who participate in the challenge of planning, administering, and assessing the telecommunications sector in developing countries.

\section{METHODOLOGY}

This work employs the case study, which draws upon multiple data sources to develop converging lines of inquiry or triangulation when investigating a specific, contemporary phenomenon. This study, based on field work conducted in Botswana in the summer of 2000, draws on three primary sources of evidence: documentation, archival records, and elite interviews. Documentation sources include, among other references, policy and legal documents from the Southern African Transport and Communications Commission (SATCC), an organ of SADC, and the Telecommunications Regulators Association of Southern Africa (TRASA). Archival records draw upon records of the telephony service pro- 
viders under analysis, namely the Botswana Telecommunications Corporation, Mascom Wireless and Vista Cellular. In gathering data, open-ended interviews were conducted with a variety of people intimately involved with Botswana's telecommunications sector, including the principal economist of the Ministry of Works, Transport and Communications, the chief executive officer of Mascom Wireless, the general manager of Vista, and staff of the Botswana Telecommunications Corporation (BTC) as well as the executive chairman and other staff members of the regulatory agency in Botswana, the Botswana Telecommunications Authority (BTA) (1997).

\section{Socio-economic profile of Botswana}

Despite its small population of some 1.5 million people scattered across a semi-arid terrain of more than $580,000 \mathrm{~km} 2$, Botswana boasts a vibrant export economy based in large part on its optimal utilization of fortuitous mineral deposits, notably diamonds. After a protracted search of 12 years, the discovery of diamonds in 1967 dramatically altered the rate of development in Botswana. According to a Presidential Task Group for a Long Term Vision for Botswana (1997, p. 15), between 1966 and 1995 Botswana's per capita GDP witnessed an average annual increase of around $6 \%$. In per capita terms, Botswana's foreign exchange reserves are among the highest in the world and the country is considered one of the richest non-oil producing states in Africa. It has enjoyed a healthy balance of payments surplus since 1985. Due to sound public sector management, its key debt ratios, negligible in comparison with other developing countries, effectively result in net negative external debt. The country's economic health, however, is overly dependent on diamonds, precariously so, as diamonds contribute on average to $75 \%$ of export earnings, one-third of GDP and more than one half of government revenue (Siddiqi, 1999, p. 6).

Botswana's characterization as one of the few African success stories is not due, though, entirely to diamonds. As noted elsewhere on the continent, natural resources, such as oil, are readily exploited with no general economic benefits en- suing, indeed high external indebtedness can be retained under such circumstances. Botswana, however, has profited from strong national unity and good and stable governance. The government is styled on a Westminster system with an executive President as head of state and government. Although the country boasts several political parties with elections held every 5 years, the Botswana Democratic Party (BDP) has been in power since independence in 1966. Furthermore, despite the turbulence in the region, Botswana has remained unmarred by war.

These positive attributes not withstanding, the country does face obstacles to its continued growth and expansion. Notably, the country must diversify its economy and its trading partners for, like other countries in the region, it is highly dependent on the Republic of South Africa whose economic fluctuations directly affect Botswana. A downturn in the South African economy in 1999 adversely affected industrial production, specifically automobiles. According to Siddiqi (1999, pp. 6 and 7), approximately 95\% of vehicles assembled in Botswana are exported to South Africa and some $70 \%$ of consumer imports are from South Africa. Furthermore, Botswana's currency, the pula, is pegged to a basket of currencies, $60 \%$ of which is dominated by the weighting of the South African rand. To maintain the competitiveness of manufactured exports to South Africa, writes Siddiqi (1999, p. 7), the rand will continue to be targeted by the central bank's exchange rate policies. Employment in the country too must be remedied. Although the official unemployment rate is $21 \%$, unofficial estimates place it closer to $40 \%$. In the course of economic diversification, the employment issue too must be redressed.

Fully cognizant of the perils of a monocommodity economy, albeit one based on diamonds, the government has introduced fiscal policies aimed at fostering economic diversification. Other than the vehicle assembly industry and a soda ash plant, efforts to diversify the economy have to date witnessed little success. The Botswana Ministry of Finance and Development Planning, however, recently approved and published the Privatisation Policy for Botswana 
Government Paper No. 1 of 2000 (2000, p. 3), in which the government clearly seeks the promotion of economic diversification and non-mining, private-sector-led growth. To ensure that the country's economic growth and pace of development are not constrained by an inefficient telecommunications network, the government of Botswana has not only invested in the sector, but also restructured it.

\section{TELECOMMUNICATIONS RESTRUC- TURING}

Like other African states, upon independence, the government of Botswana established a single post and telecommunication service that integrated regulatory functions with operational and decision making functions. The government essentially created a state monopoly with some fundamental problems ensuing. These problems, writes Lekaukau (1997, p. 2), included little to no competition in the provision of services, limited private sector participation, lack of transparency in the decision making process, and no opportunity for consumers to voice their concerns. It is in this environment, common to most African countries, that a restructuring of not only the telecommunications sector, but also the state apparatus, must be carried out.

\section{Botswana Telecommunications Corporation}

Although an Act of Parliament established the Botswana Telecommunications Corporation (BTC) and separated it from the Botswana Postal Services in 1980, the new telecommunications service provider retained its regulatory powers and monopoly status. When the BTC was created, it inherited a customer base of 6500 subscriber lines, no pay phones and 175 telex subscribers (Datapro, 1998, p. 2). The BTC has since grown into one of the most advanced networks in Africa. It has, however, experienced its achievements largely under the management of UK-based Cable and Wireless, for, according to a report in Southern Africa Telecom Quarterly by The Southern Africa Regional Telecommunications Restructuring (RTR) Program (1996, p. 2), from
1980 through 1995 the BTC operated under a management contract with Cable and Wireless. Today it maintains a fully digital microwave backbone ring supplemented by high-capacity, fibre optic links with digital exchanges at the main centres. In its Annual Report 1999, the Botswana Telecommunications Corporation reports that with more than 100,000 customer access lines in service, there are now more than 6.4 telephones for every 100 people in the population which is one of the highest indicators in Africa. According to BTC $(1999$, p. 1) the current network comprises $7300 \mathrm{~km}$ of microwave radio and fibre optic links between 12 main processors each of which serves a particular area of the country and the switching units possess a capacity of some 117,000 lines.

The BTC offers a variety of services, including, among others, national and international telephony, private wires, leased circuits, very small aperture terminals, toll-free services, paging, public telephones, voice messaging, and packet switching. The Corporation is also one of three Internet service providers in the country. The BTC has successfully met most of its financial goals and again produced record revenue and earnings for the 1998/99 financial year. Yet despite boasting one of the most modern telecommunications infrastructures in Africa and its financial success, the Ministry of Works, Transport and Communications found the BTC to be wanting in terms of its ability to serve the Batswana and the country's developing economy. Although a monopoly service provider is a common structure in many countries, the Ministry (1995, p. 8) stated in its policy paper that the BTC had been unsuccessful in providing efficient services and could not be expected to meet the needs of the future.

\section{Ministry policy paper of 1995}

In 1992 the government directed the Ministry of Works, Transport and Communications to formulate polices to overhaul the telecommunications sector. In October 1994, a consultancy contract was awarded to a consortium consisting of Swedtel and ISO-Swedish Management Group to 
advise in the restructuring of the sector. Conscious of the broad implications of telecommunications reform, the Swedish consortium and officials of the Ministry of Works, Transport and Communications conducted nation-wide consultations during the first half of 1995. In a process, which can best be described as one of democratic participation, interviews were conducted with Village Development Committees, members of the business community, as well as District and Council Administrations (Republic of Botswana, Ministry of Works, Transport and Communications, 1995, p. 5). This ambitious effort enabling the public to air their concerns and clarify their telecommunications needs is an undertaking most worthy of replication in other African states.

Furthermore, the participation of users and the protection of consumers is one of the five basic principles upon which the liberalisation process in Botswana is based. Since the Ministry (1995, p. 8) considered the BTCs financial and human resource constraints as responsible for the creation of an imbalance in supply and demand of telecommunications services, they contended it was necessary to add private resources to the industry to exploit the sector as a means for national development. Thus two other principles guiding telecommunications policy include competition as a means to increase efficiency and participation of the private sector. Transparency in decision making to promote investor confidence and an independent regulatory agency comprise the final policy principles. These five principles in sum form the cornerstone of two critically important pieces of legislation, the Telecommunications Act, 1996-Act No. 15 of 1996 (Republic of Botswana, 1996b) and the Botswana Telecommunications Corporation (Amendment) Act, 1996-Act No. 16 of 1996 (Republic of Botswana, 1996a). These two pieces of legislation, both passed by the National Assembly on the 1st of August 1996, define the development of the telecommunications sector in Botswana for the foreseeable future. They reflect the country's commitment to three main national goals: universal service, efficient service, and regional balance.

\section{Botswana Telecommunications Corporation (Amendment) Act, 1996}

The main objective of the Botswana Telecommunications Corporation (Amendment) Act, 1996Act No. 16 of 1996 is to enable the introduction of competition in the telecommunications sector. This piece of legislation thus abolishes the BTC's monopoly in the provision of telecommunications services. It eliminates the BTC's authority to prescribe the tariffs at which it provides telecommunications services. Also terminated are the BTC's powers to make by-laws and regulations. The Amendment or Act (1996, pp. B. 137 and B. 139) repeals the Botswana Telecommunications Corporation Regulations, and in Part II it establishes a telecommunications regulatory authority.

\section{BOTSWANA TELECOMMUNICATIONS AUTHORITY}

\section{BTA Board}

The powers and functions of the BTA are exercised and performed by a five member Board. This statutory Board enjoys a great deal of autonomy. This concurs with the Ministry's policy paper $(1995$, p. 19) which suggested that a regulatory authority as independent of the Ministry as legally possible should be created, for international experience demonstrates that the more autonomy and political latitude given to the regulator, the more successful the liberalisation process. All of the members of the Board are, however, appointed by the Minister of Works, Transport, and Communications. Mr. Lekaukau serves as the Chairman of the Board as well as the Chief Executive of the BTA. One member is a representative of the Ministry of Finance and Development Planning and another is a representative of the Ministry of Commerce and Industry. In an effort to ensure public representation, one person is appointed who represents the business community and another person is selected to repre- 
sent the domestic users of telecommunications services. This latter appointment is in line with the Board's mandate to protect consumer interests and particularly since consumer councils have yet to be established. To attempt to neutralize special interests, the Telecommunications Act (1996, p. B. 143) states that no person is qualified to serve on the Board who "has any interest in a licence or in the holder of licence, or is the holder of a licence issued under this Act."

\section{Responsibilities of BTA}

The BTA, which was created to achieve a tripartite arrangement with the Government as the policy maker, the Authority as the regulator, and the BTC as an operator together with other operators in a competitive environment, was officially established on the 20th of December, 1996, when Parts I-V of the Telecommunications Act were brought into force. The BTA did not, however, assume its licensing powers until July 1st, 1997. In an effort to promote and supervise the provision of efficient and competitive telecommunications services in Botswana, the BTA, writes Lekaukau (1997, p. 7), is charged with various responsibilities, including the issuing of service licences, systems licences, and radio licences; the issuing of regulations governing the industry; spectrum management; type-approval of telecommunications equipment and systems; issuing of tariff guidelines and approval of tariffs; and the settling of disputes among stakeholders (operators, end-users, etc.). According to the former Minister of Works, Transport and Communications, Kwelagobe (1997, p. 2), although the BTA holds powers not previously held by the BTC, transitional arrangements with the BTC with respect to the transfer of its regulatory functions were not, as to be expected, always a smooth process. Further, the very act of licensing the BTC as another operator in a competitive environment was a dramatic change for the former monopoly service provider.

According to the Group Manager for Corporate Business and Regulatory Affairs at the BTC, Mmasekgoa Masire-Mwamba (personal communication, July 5, 2000), it was not until mid-1998 that the BTC began feeling the effects of the BTA, of being a regulated monopoly instead of a monopoly, despite the fact that a performance contract was never instituted. The Ministry (1995, p. 15) had recommended in its policy paper that a performance contact between the government and the BTC be created which would stipulate the BTC's responsibilities for operating, expanding and maintaining the network. The BTA hired consultants who assisted in drafting a performance contract in which the BTC's noncompetitive operations, that is, its fixed network services would be regulated, for its competitive operations are carried out separately. The contract, though internally created, was not, however, enacted. It may have been deemed unnecessary to institute the contract since the government, in accord with its recently issued Privatization Policy, is considering the privatization of the BTC.

The BTC currently operates under the 1 year licence that was granted by the BTA in March 2000 until a long-term licence is completed. Although the BTC is gradually adjusting to the new regulatory regime and to competition in the form of cellular service providers, one area with which the BTC takes issue is the way in which disputes are settled. In its policy paper, the Ministry (1995, p. 19) recommended that the decisions of the regulatory authority should not be able to be overruled by the Minister of Works, Transport and Communications, but could be appealed in the High Court. In the Telecommunications Act (1996, p. A. 147) it was thus enacted that the decisions of the BTA can only be appealed in the High Court of Botswana. The exception is with respect to the decisions relating to the approval of tariffs where appeals are made to the Minister to avoid any delays due to lengthy court procedures, as such delays are not conducive to the market place (Lekaukau, 1997, p. 7).

The BTC, however, would prefer a different arbitrary mechanism, contends Mmasekgoa Masire-Mwamba (personal communication, July $5,2000)$. The public consequences of going to court and the consequent media coverage can prove awkward for the BTC. The BTA required 
that the BTC commence billing on a per second basis, but the BTC has had difficulty complying with this request as it has experienced problems in implementing its new billing system and as a consequence has suffered poor public relations. Further, the BTC would lose revenue if it billed on a per second basis since customers are currently billed for directly dialed local calls on an incremental basis of minutes. The BTC will also witness a loss of revenue with the reduction of zones, which the BTA has required, for the BTC currently charges various rates for calls within and between zones. To address these areas of contention in the High Court would prove disastrous for the BTC in terms of its public profile. Thus, it would prefer an arbitrator with industry expertise housed in the Ministry.

Sufficient staff with such expertise, however, appears to be lacking. Although the Ministry's policy paper (1995, p. 19) indicated that the regulatory authority should handle some policy functions on behalf of the Ministry, the BTA does a lot of work for the Ministry for which they should in fact be responsible. It also acts as the government's representative in regional and international bodies that deal with telecommunications issues, such as the International Telecommunications Union, the Commonwealth Telecommunications Organisation, and the World Trade Organisation. At the regional level the Authority was elected to the Executive of the Southern African Development Community (SADC) regulators association known as the Telecommunications Regulators Association of Southern Africa (TRASA). The BTA was also instrumental in the creation of the Telecommunications Model Policies and Legislation for SADC that was adopted by the relevant SADC Ministers on June 26th, 1998 (BTA, 1998/1999, p. 11). The BTA must be highly commended for these activities, yet it is nonetheless advisable to avoid the duplication of expertise in both the Ministry and the BTA, thus clarification of requisite responsibilities is needed, especially in light of the fact that the BTA is to be selfsufficient in terms of financing.

\section{Financing of BTA}

In its policy paper the Ministry (1995, p. 18) considered that the cost of regulating the industry should be borne by the industry itself as much as possible by levying fees and charges for the licensing of operators and equipment that reflect the real cost of providing the services. According to Part II of the Telecommunications Act, (1996, p. B. 144) the BTA's funds shall consist of

(a) such fees as the Authority may impose for services provided under this Act; (b) such fees as the Authority may impose for licences issued under this Act; (c) such moneys as may be appropriated by the National Assembly; (d) contributions or endowments from any other source; and (e) such other fees or moneys as the Authority may by virtue of this Act, raise or impose.

The government of Botswana provided a seed grant in 1997 and initial assistance by both the governments of Botswana and Sweden was used to hire experts through the Swedish Management Group (SMG), formerly ISO Management Group. Additional external support came from the United States government through the USAID Southern Africa Regional Telecommunications Restructuring Programme, a 5 year project contracted to Price WaterhouseCoopers that concluded in the fall of 1999. Not withstanding such support, though, the BTA has proven to be a viable, self-sustaining entity. It has also successfully introduced mobile telephony in the country. Indeed, the BTA must be commended for its rapid licensing process.

\section{CELLULAR SERVICES}

Having become operational in early 1997, the BTA moved quickly to address what the former Minister of Works, Transport and Communications, Kwelagobe (1997, p. 5) considered the "most urgent agenda item for the authority," that is, the licensing of cellular services. The newly created regulator published its plans in 
May 1997 to license cellular services throughout the country and set a stringent timeline of August 1997 as the closing date to submit proposals. All of the proposals submitted were joint ventures since the BTA in its Invitation to Tender for $\mathrm{Li}$ cences to Provide Mobile Telecommunications Service in Botswana (1997, p. 13) required the tenderer to provide proof of commitment to incorporate a company in Botswana and specify what the minimum paid up share capital would be and what proportion would be held by Botswana owners. The company's local employment policy, training policy and the transfer of technology were also considered in the evaluation process. These aspects of the tendering process, among others, such as the speed and transparency of the process, warrant emulation in other African states.

Five proposals were received and opened on August 12th, 1997. According to a report published by the USAID-funded Southern Africa Regional Telecommunications Restructuring Program (1998, p. 2) these included: (1) BhartiTCLI Afrocell (Botswana) Limited, a joint venture of two companies from India and Mauritius with local partner Jamal Trading Company; (2) the MTN (Botswana) Consortium, a combination of MTN Holdings of South Africa with the local partner Loapi Holdings Limited; (3) Botswana Vodacom Cellular, a joint venture of Vodacom Group of South Africa and the Botswana Telecommunications Corporation; (4) Vista Limited, a combination of France Telecom and several local investors including Hemano Investments, Thusanyo Investments, Inter Public, Omega Holdings, and Leno Holdings; and (5) Mascom Wireless Consortium, a joint venture between Portugal Telecom International, Zimbabwebased T.S. Masiyiwa Holdings and local partner Deci Holdings. Although short-listed, it is indeed noteworthy that the state-owned service provider, the BTC, was not awarded a licence, as is generally the case in most African states. Rather, writes Lekaukau (1999, p. 21), after successfully negotiating the terms and conditions of operation, Vista Limited and Mascom Wireless Consortium were each awarded a licence in February of 1998 to install, operate and maintain a GSM
Mobile Cellular Public Telecommunications Network.

\section{Licence conditions}

The licences are both valid for a period of 15 years and renewable, though after 5 years competition may be introduced to the market as additional cellular licences may be awarded. Since the licences were granted to provide the widest possible coverage, the two licence packages have equal coverage rights in the densely populated area of Botswana, which is between Lobatse and Francistown, though each has a different mandatory coverage area. Mascom has mandatory coverage obligations in some villages between Francistown, Kasane and Maun while Vista's obligatory coverage is between Lobatse, Gantsi and Mamuno (Lekaukau, 1999, p. 21). According to the BTA in the Licences Granted by Botswana Telecommunications Authority to Mascom Wireless (PTY) Limited and Vista Cellular (PTY_ Limited Under Sections 27 and 28 of the Telecommunications Act of 1996 (No. 15 of 1996) BTA (1998, pp. 18-19), each licensee was granted 48 months to provide full coverage for the mandatory coverage areas. Upon compliance with the rollout schedule for their mandatory areas, either operator can provide service anywhere they choose including the competitor's mandatory coverage area. The BTA has thus granted each operator's request to provide service to parts of the country not originally in their licences (Lekaukau, 1999, p. 23).

In relation to sharing facilities, within 12 months of the licence date each licensee was required to make National Roaming Access available, meaning access to the network by a GSM user of any similarly licensed operator who is not a customer, that is to say, customers of one network are able to use another network in areas where their operator does not provide service. Furthermore, each licensee was required, as stipulated by the BTA in the Licences (1998, pp. 15 and 19), to ensure the provision of international roaming by negotiating roaming agreements with operators in other countries as well as provide and share with other operators a directory infor- 
mation service. In constructing the networks, it was also expressly stipulated that each licensee minimise any negative environmental impact and give preference to Botswana citizens and products in the implementation and operation of its networks. These later requirements of the licence are not only notable, but especially worthy of emulation, as are the fee arrangements since they assist in securing the independence of the regulator.

In addition to the initial licence fee of P1,000,000 (one million Pula or approximately US $\$ 250,000$ at the current exchange rate of US\$1 for P4), each cellular operator, as specified by the BTA in the Licences (1998, pp. 11-12), must pay an annual system licence fee of $\mathrm{P} 150,000$ or US\$37,500, an annual service licence fee of P150,000 or US\$37,500, an annual radio licence fee of $\mathrm{P} 300,000$ or US $\$ 75,000$ as well as a revenue fee. The revenue fee is equal to $5 \%$ of the company's total revenue. Other fees, noted in the licence, are applicable if the licensee fails to meet the terms of the licence. For example, the BTA states in the Licences (1998, p. 18) that the licensee shall be penalized $\mathrm{P} 100,000$ or US $\$ 25,000$ for each month it fails to meet the requisite rollout time frame. The licensee is also required to spend a minimum of $0.25 \%$ (one quarter of $1 \%$ ) of its annual net turnover on developmental activities related to the telecommunications or information industry.

These latter expenditures constitute the company's requisite social obligations. The company can choose which social service programmes related to the telecommunications industry or information society it funds. The programs include, though are not limited to, education and training projects, bursary schemes and the supply of technology, such as to schools or hospitals, provided that the activities are not directly related to the licensee's own operations or employees. The licensee may, however, states the BTA in the Licences(1998, p. 11), derive subsequent or indirect benefit from any developmental activities. The programmes the licensee opts to sponsor must be approved by the BTA. For example, according to the General Manager of Vista, Har- ry Ward (personal communication, July 7, 2000), Vista sponsors a program enabling children who are victims of abuse to make free telephone calls to seek counselling and get assistance. Each licensee is also required to provide free emergency service calls as well as install a minimum of 500 public telephones within a 4 year period.

Pay phones are essential to thousands of people in Botswana, especially those living in rural areas where they provide a critical connection to the rest of the country. The BTC's policy has historically been to provide a public pay phone and telephone to every village with a population of at least 500 people. Since the revenue generated from rural telecommunications services did not cover the development and maintenance costs of these services, the monopoly cross-subsidized the service with revenue from urban areas and large villages. According to the BTC $(1997 / 1998$, p. 4), there is a need to identify a new funding mechanism for rural telecommunications since the BTC is now to operate on a competitive basis. The government of Botswana could subsidize the tariffs for the rural areas, provide the funds for the capital costs of rural telecommunication projects, and/or establish a universal service fund. The Ministry (1995, p. 7) states that the government recognizes basic telephony as a citizen's right, comparable with the right to basic education and primary health care. Thus, the community services provided by the cellular operators contribute to improving telecommunications accessibility and such social obligations have in no way adversely affected the operators. To the contrary, they benefit from the positive public relations associated with the programs they fund.

\section{Cellular success}

Although the initial expectation was that it would take 10 years to reach 100,000 customers, after 28 months, notes the Chief Executive Officer of Mascom, Luciana P. da Costa (personal communication, July 6, 2000), Mascom boasted more than 100,000 subscribers and will soon surpass the BTC in terms of its subscriber base. The customer base of the two cellular companies com- 
bined, however, does exceed that of the BTC. According to the General Manager of Vista, Harry Ward (personal communication, July 7, 2000), Vista, which experienced some early management and promotional difficulties, has a customer base of more than 50,000. Like Mascom, its growth too has surpassed the original projections of its initial business plans. Both companies witnessed rapid growth after November 1998 when prepaid services were introduced. Some $90 \%$ of Mascom and Vista's customers are prepaid. Continued growth is expected in the mobile market as the companies continue to launch more services for specific markets.

\section{Vision 2016}

The government of Botswana is firmly committed to the growth of the telecommunications sector. As stated by the Presidential Task Force in its Long Term Vision for Botswana or Vision 2016 (1997, p. 35), "it is vital that there is an increased investment in telephone connections and international communications through Internet services." In recognizing that the 21 st century is ushering in an information-driven global economy and society, the Task Force recommended the formulation of a national information vision as well as information technology strategies. The Task Force (1997, p. 35) further stated that the country must introduce a freedom of information act to protect the rights of citizens to have access to information and to ensure the accountability of all public and private institutions. The government also seeks to position the country as a regional supplier of telecommunications services.

\section{CONCLUSIONS}

Botswana exemplifies a controlled liberalisation of the telecommunications industry. It is successfully proceeding to open its telecommunications market to competition, foreign capital and new technologies. Effective basic regulatory capacity was instituted in what can be considered record time, and yet regulation of the liberalised tele- communications sector is relatively new in Botswana and necessary systems and tools are still under development. While addressing such difficult issues as spectrum reallocation, interconnection and privatisation, the BTA must simultaneously institutionalise its internal structure and procedures. Although telecommunications liberalisation in many countries has regrettably led to additional regulations and newly appointed bureaucrats emerging as substitutes for the former monopolies, Botswana is attempting to create an incentive driven and lean regulatory regime. Price cap models, standardised licence conditions and uniform reporting systems facilitate the regulator's work. Regulatory measures that are simple to implement and supervise and which reduce the workload and political burden on the regulatory agency are being developed by the BTA. Most importantly, though, the BTA is effectively making the telecommunications sector an integral component of the country's national development efforts.

The two enactments, the Telecommunications Act, 1996-Act No. 15 of 1996; and the Botswana Telecommunications Corporation (Amendment) Act, 1996-Act No. 16 of 1996, form the basis of telecommunications regulation for the country's foreseeable future; in due course experience will determine whether they are satisfactory or not. Certainly, however, the abolition of the monopoly position of the BTC coupled with mobile telephone subscribers has significantly increased the teledensity of the country. As the government considers the creation of an umbrella utilities regulatory agency as well as the privatisation of the BTC, further progress in regard to developments in the telecommunications industry in Botswana are anticipated. Such progress could be replicated in other African states should they embrace a similar strategy as that adopted in Botswana to restructure the telecommunications sector.

\section{ACKNOWLEDGEMENTS}


The author would like to thank Howard University for the New Faculty Grant which facilitated this research.

\section{REFERENCES}

Botswana Telecommunications Authority (BTA). (1997). Invitation to Tender for Licences to Provide Mobile Telecommunications Services in Botswana. Gaborone, Botswana, May.

Botswana Telecommunications Authority (BTA). (1998). Licences Granted by Botswana Telecommunications Authority to Mascom Wireless (PTY) Limited and Vista Cellular (PTY_Limited Under Sections 27 and 28 of the Telecommunications Act of 1996 (No. 15 of 1996). Gaborone, Botswana.

Botswana Telecommunications Authority (BTA). (1998/1999). Annual Report 1998/1999. Gaborone, Botswana.

Botswana Telecommunications Corporation (BTC). (1997/1998). A Report on the Development of Rural Telecommunications in Botswana. Gaborone, Botswana.

Botswana Telecommunications Corporation (BTC). (1999). Annual Report 1999. Gaborone, Botswana: AFG Printers.

Datapro. (1998). Botswana: The Commercial and Regulatory Environment. Datapro Reports on International Telecommunications. Datapro Information Services, March.

Kwelagobe, D.K. (1997). Speech by Hon. D.K. Kwelagobe, Minister of Works, Transport and Communications on Botswana Telecommunications Authority in the National Assembly, 8 April. Gaborone, Botswana.

Lekaukau, C.M. (1997). The Liberalisation of Telecommunications Services in Botswana. Keynote Address. Presented at the Workshop on Tariffs, Interconnect and Related Costing Issues, 13 October. Gaborone, Botswana.
Lekaukau, C.M. (1999). Briefing on Botswana Telecommunications Authority: Functions and Responsibilities, 16 November. Gaborone, Botswana.

Presidential Task Group for a Long Term Vision for Botswana. (1997). Long Term Vision for Botswana: Towards Prosperity for All, September. Botswana Government Printer, Gaborone.

Republic of Botswana. (1996a). Botswana Telecommunications Corporation (Amendment) Act, 1996-Act No. 16 of 1996, 1 August. Botswana Government Printer, Gaborone.

Republic of Botswana. (1996b). Telecommunications Act, 1996-Act No. 15 of 1996, 1 August. Botswana Government Printer, Gaborone.

Republic of Botswana, Ministry of Finance and Development Planning. (2000). Privatisation Policy for Botswana. Government Paper No. 1 of 2000. Botswana Government Printer, Gaborone.

Republic of Botswana, Ministry of Works, Transport and Communications. (1995). Telecommunications Policy for Botswana, December. Botswana Government Printer, Gaborone.

Siddiqi, M. (1999). The African Success Story. Africa Economic Digest, 17 May, pp. 6-7.

The Southern Africa Regional Telecommunications Restructuring (RTR) Program. (1996). Botswana: In Profile. Southern Africa Telecom Quarterly, 1(2), 1-5. Available: http://rtr.worldweb.net/profile_bots.htm [1999, June 21].

The Southern Africa Regional Telecommunications Restructuring (RTR) Program. (1998). SADC Special Report: Cellular Services Comes to Botswana, 27 May (pp. 1-4). Available: http://rtr.worldweb.net/botswana-cellular0598.htm [1999, June 21]. 